\title{
The use of degraded and shade cocoa forests by Endangered golden-headed lion tamarins Leontopithecus chrysomelas
}

\author{
Becky E. Raboy, Mary C. Christman and James M. Dietz
}

\begin{abstract}
Determining habitat requirements for threatened primates is critical to implementing conservation strategies, and plans incorporating metapopulation structure require understanding the potential of available habitats to serve as corridors. We examined how three groups of golden-headed lion tamarins Leontopithecus chrysomelas in Southern Bahia, Brazil, used mature, swamp, secondary and shade cocoa (cabruca) forests. Unlike callitrichids that show affinities for degraded forest, Leontopithecus species are presumed to depend on primary or mature forests for sleeping sites in tree holes and epiphytic bromeliads for animal prey. In this study we quantified resource availability within each habitat, compared the proportion of time spent in each habitat to that based on availability, investigated preferences for sleeping site selection, and determined how goldenheaded lion tamarins allocated time to foraging behaviour in different habitats. Each group preferred to range in certain habitats during the day, yet patterns were not
\end{abstract}

consistent across groups. In contrast, all groups preferred to sleep in mature or cabruca forest. Golden-headed lion tamarins spent a greater proportion of time foraging and eating fruits, flowers and nectar in cabruca than in mature or secondary forests. Although the extent to which secondary and cabruca forests can completely sustain breeding groups is unresolved, we conclude that both habitats would make suitable corridors for the movement of tamarins between forest fragments, and that the large trees remaining in cabruca are important sources of food and sleeping sites. We suggest that management plans for golden-headed lion tamarins should focus on protecting areas that include access to tall forest, either as mature or cabruca, for the long-term conservation of the species.

Keywords Atlantic rainforest, Brazil, Callitrichidae, golden-headed lion tamarins, habitat use, Leontopithecus chrysomelas, shade cocoa, Southern Bahia.

\section{Introduction}

The dramatic increase in human populations has had a large negative impact on tropical forest (Turner et al., 1990). As a result of shifting agriculture and logging practices, habitat loss, degradation, and fragmentation threaten the existence of many primate species (Johns, 1991). The ability of primates to use degraded forests varies widely and may depend on body size and the type and diversity of their diet (Johns \& Skorupa, 1987). To the extent that the characteristics of forests may differ among primary, secondary, logged or agro- forests, so does a species' ability to exploit these environments.

Becky E. Raboy (Corresponding author) and James M. Dietz Department of Biology, University of Maryland, College Park, MD 20742, USA. E-mail: raboyb@mail.nih.gov

Mary C. Christman Department of Animal and Avian Sciences, University of Maryland, College Park, MD 20742, USA.

Present address: Department of Conservation Biology, Conservation and Research Center, National Zoological Park, Smithsonian Institution, Washington, DC 20008, USA.

Received 11 September 2002. Revision requested 30 January 2003. Accepted 20 June 2003.
Variation in the height of the forest, openness of the canopy, canopy connectivity and diversity, and abundance of resources can affect how a primate uses a particular habitat.

Many species of tamarins and marmosets (Callitrichidae), small New World primates, use disturbed and regenerating forests and are often considered 'edgespecialists' (Terborgh, 1983; Sussman \& Kinzey, 1984; Rylands, 1986, 1996; Egler, 1992; Passamani \& Rylands, 2000). Callitrichids eat fruit, insects, small vertebrates, and plant exudates, resources that vary in availability across habitats and in some cases may be abundant in degraded or secondary environments. In the relatively open canopy of secondary forests light penetrates easily, leading to a large quantity of fruit, flowers and foliage (Blake \& Loiselle, 2001). The abundance of small fruits may explain why many migrating bird species frequently use secondary forest (Martin, 1985). However, it is not always clear that secondary forests have more fruit available than mature forest, and some suggest the opposite (Ferrari \& Diego, 1995). Other key resources may influence the success with which callitrichids use secondary habitats. The thick undergrowth that is typical of regenerating forests may also provide protection from 
predators and structural support that facilitates travel (Rylands, 1996). Additionally some callitrichids, such as the genus Callithrix, have a specialized dental structure that enables them to easily consume gums obtained from trees and vines (Sussman \& Kinzey, 1984). These specializations allow for efficient exploitation of disturbed forest when fruit is not available (Ferrari \& Diego, 1995).

Lion tamarins (Leontopithecus spp.) are presumed to depend on mature forests for two principal resources that may be less abundant in secondary forests (Rylands, 1989, 1996). The first is tree holes for sleeping (Rylands, 1993). Although some species of Callithrix (Rylands, 1982, 1986) and tamarins from the genus Saguinus (Terborgh, 1983) occasionally sleep in tree holes, Leontopithecus spp. are the only callitrichids studied that habitually do so (Coimbra-Filho, 1978). Secondary forests are thought to have fewer tree holes of adequate size, especially in younger forests comprised of trees of small diameter (Coimbra-Filho, 1978; Rylands, 1993). The second resource is epiphytic bromeliads, sites where lion tamarins frequently forage for animal prey. Lion tamarins have long, slender hands, relative to other callitrichids, that aid in manipulative foraging (Rylands, 1993; Bicca-Marques, 1999). For three of the four species of Leontopithecus, bromeliads are a preferred foraging microhabitat for locating prey (Rylands, 1982; Peres, 1986; Prado, 1999; Raboy, 2002).

Irrespective of potential habitat preferences, lion tamarins are forced to use degraded forest because of the widespread destruction of mature forest (Rylands et al., 1996). Lion tamarins are endemic to the Atlantic forest (Rylands et al., 1996), one of the most threatened tropical forests in the world (Mittermeier et al., 1982). This forest is now a mosaic of primary and secondary forest, and agricultural lands (Stallings \& Robinson, 1991), with only 2-8\% remaining forest (Mallinson, 2001; Saatchi et al., 2001). Leontopithecus spp. are categorized as either Endangered (Leontopithecus chrysomelas) or Critically Endangered on the 2002 IUCN Red List (L. rosalia, L. chrysopygus and L. caissara; IUCN, 2002).

An understanding of the habitat requirements of lion tamarins is important for the design of conservation strategies. Plans incorporating metapopulation structure require discerning the potential of different habitats to serve as corridors for movement between larger tracts of forest (Lidicker \& Koenig, 1996). Given the rapid degradation of Brazil's Atlantic forest, understanding how lion tamarins use regenerating forests and agricultural land is essential for prioritizing areas for conservation. For example, much of the eastern part of the range of goldenheaded lion tamarins has been converted into agroforests known as cabruca. Cabruca is a system of shade cropping in which the middle and understory trees of intact forests are removed and replaced with cacao trees
Theobroma cacao. Cabruca has relatively few lianas and a reduced subcanopy, substrates that are commonly used by callitrichids. Prior to this study, it was not clear how successfully lion tamarins were able to use this habitat.

In this study we examine the extent to which goldenheaded lion tamarins L. chrysomelas use available habitats. In particular, we determine resource density within each habitat and compare patterns of habitat use to availability, including whether golden-headed lion tamarins have preferences for the location of sleeping sites. In addition, we look at patterns of foraging behaviour in each of these habitats, consider the impact that cabruca and regenerating forest have on lion tamarin ecology, and highlight the importance of these habitats for successful conservation of the species.

\section{Methods}

We conducted our study in and near Una Biological Reserve in Southern Bahia, Brazil (Fig. 1). Points mapped with a global positioning system, ground surveys, historical records of land-use and aerial photographs were used to create a map outlining mature, secondary, swamp and cabruca forest. Swamps were classified as a distinct habitat type, regardless of whether they contained mature or secondary forest. Mature forest was characterized by a canopy at 25-35 m height, an abundance of epiphytes and vines and a relatively open understory. Cabruca had a similar height and presence

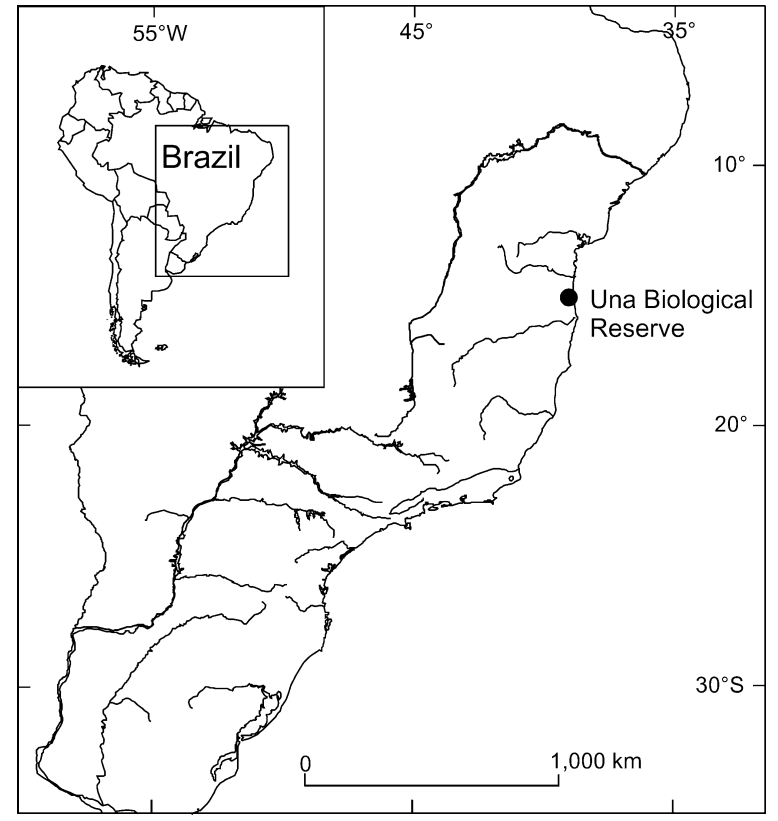

Fig. 1 The eastern coast of Brazil, indicating the location of Una Biological Reserve; the inset indicates the location of the main figure (map courtesy of Paulo de Cordeiro). 
of epiphytes, but was distinguished from mature forest by the presence of cacao and banana trees, a sparser understory and mid-canopy, and an absence of vines. Secondary forests at our study site generally had canopies at 5-10 m, and occasionally at $15 \mathrm{~m}$, with trees of small diameter and dense, scrubby understory. Secondary forests also included small areas of newly regenerating fields with few trees and mainly bushes and grasses. Swamp was characterized by muddy ground or standing water, usually in stream valleys, and had the densest understory.

To census lion tamarin resources we sampled along eight $5 * 100 \mathrm{~m}$ transects in each of the four habitats. The locations of transects in mature, secondary and cabruca forest were determined randomly. Swamp habitats were found in few locations and were chosen non-randomly. We counted the total number of trees in each transect using four size classes based on diameter at breast height $(10-20,20-30,30-40$ and $>40 \mathrm{~cm})$. We counted all bromeliads in each of three size classes $(0-20,20-40$ and $>40 \mathrm{~cm}$ ), determined by estimating the basal diameter. The number of piaçava palms Attalea funifera, dendê palms Elaeis guineensis, and rotting-wood sites, all common foraging microhabitats for lion tamarins, were also counted. Every $10 \mathrm{~m}$ along the transect all visible tree holes within a $2.5 \mathrm{~m}$ radius of the midline of the transect were recorded. Each $5 * 10 \mathrm{~m}$ quadrat within a transect was classified as having a presence or absence of vines connecting trees.

We studied three groups, named Piaçava, Onça, and Entulho, consisting of eight, nine and six individuals respectively, between 1998-2000. Each group used mature, secondary and swamp forests. Piaçava and Onça also used cabruca but this habitat was not available in the home range of Entulho. We followed methods from Dietz et al. (1996) to capture and habituate individuals to the presence of human observers. Systematic observations were taken on groups Piaçava, Onça and Entulho on 92, 70 and 45 complete days, respectively, from the time they left their sleeping sites in the morning to the time they returned in the late afternoon. Every 20 minutes we conducted scan sampling (Altmann, 1974). The identity and behaviour of all visible group members were recorded at the first instance they were observed during a 4-minute scanning period.

In order to characterize the groups' preferred habitats, we required information about each group's home range and the distribution of habitats within that home range. Home ranges were determined by recording the location of the group's centre, estimated by using a map and marked trails as reference, every 2 hours. We used the fixed-kernel method (Worton, 1986, 1989) to calculate the area of the range, using the Animal Movement Analysis
Extension (Hooge \& Eichenlaub, 1997) for ArcView software, version 3.2 (Environmental Systems Research Institute, Inc., Redlands, USA). We overlaid the home range and habitat maps to determine the amount of each habitat in the home range of each group.

We conducted a weighted multivariate analysis of variance on the transect data to determine if overall differences in resource availability existed between habitats. The total numbers of trees, bromeliads, alternative foraging sites, and tree holes were used as the dependent variables. To test for differences in density of resources between particular habitats, we conducted multiple comparisons using the Tukey-Kramer procedure for three of the four variables. We used a logistic regression to test for variation in the probability that transects would contain lianas as a function of habitat, and conducted contrasts between all habitats using the Bonferroni method to control for experiment-wise type 1 error (Sokal \& Rohlf, 1995).

$\chi^{2}$ goodness of fit tests were used to determine habitat preferences for each group. We compared the number of scans collected in each habitat with the number expected based on availability. We used the Bonferroni $z$ statistic (Neu et al., 1974) to test whether particular habitats were used significantly more or less than expected (Dietz et al., 1997). To test the relationship between sleeping site selection and availability of habitat types, we conducted a $\chi^{2}$ goodness of fit test for group Onça and an exact test for groups Entulho and Piaçava. The distinction was necessary because of restrictions due to small sample sizes for the latter groups. Monte Carlo simulations were run to obtain an approximation of the exact distribution of the $\chi^{2}$ statistic.

To test whether or not the proportion of time allocated to foraging behaviours varied with habitat type, we used a mixed model repeated measures analysis of variance. Denominator degrees of freedom were adjusted using the Kenwood-Rodgers method. To test for differences between particular habitats, we conducted multiple comparisons using the Tukey-Kramer procedure. We excluded from analyses those individuals for which we had $<30$ scans in each habitat type. The alpha level was set at 0.05 for all statistical tests. Further details on the methods and analyses are outlined in Raboy (2002). All analyses were performed using SAS software (SAS Institute, Cary, USA).

\section{Results}

Analyses of transect surveys revealed differences in resource density among the four habitats $(P=0.002)$. Total tree density and the density of alternative foraging sites differed significantly among the four habitats. The 
difference in number of bromeliads was close to statistical significance $(\mathrm{P}=0.054)$ and pairwise comparisons revealed that secondary forests had fewer bromeliads than any other habitat. Pairwise comparisons also revealed that mature forests had higher densities of trees than cabruca and secondary forests and that cabruca had fewer alternative foraging sites than mature or swamp forests (Table 1). The presence or absence of lianas was significantly different among habitats $(\mathrm{P}<0.001)$. Fewer lianas were found in cabruca than in other forest types $(\mathrm{P}<0.001$ for all contrasts between cabruca and the other habitats, $\mathrm{a}=0.0083$ ).

Lion tamarin groups used all habitats available in their home ranges, but did not use them in relation to their availability (Table 2). Although each group showed preferences, these were not consistent among groups. Entulho did not have cabruca within their home range and instead used secondary forest preferentially. Onça had all four habitats available and preferentially used mature forest and swamp. Use of secondary forests by Onça was much less than expected. In contrast, Piaçava used most habitats in proportion to their availability with the exception of mature forest, which was used less than expected.

Piaçava, Onça and Entulho were observed to sleep in 54,65 and 38 different distinct sleeping sites respectively, averaging 1.6, 2.5 and 2.1 different locations per week. Piaçava and Onça slept only in tree holes whereas $31.6 \%$ of the sites chosen by Entulho were vine tangles located in secondary forest. Each group used sleeping sites in most habitats, but did not choose them in relation to the proportion of habitats in their home range. Sites were selected in mature or cabruca forest more often than expected based on availability of those habitats. Piaçava preferred cabruca for sleeping sites but Onça and Entulho preferred mature forests in the sense that they used those habitats for sleeping more than expected (Table 3). Each group used a few sleeping sites repeatedly (Fig. 2). Piaçava went to five sites, Onça nine and Entulho only three on $50 \%$ of the evenings they were observed. For Piaçava and Onça the locations of these most commonly used sites were in mature forest or cabruca, and never in secondary forest. In contrast, the most commonly used sleeping sites for Entulho were in secondary forest.

The proportion of the time budget that individuals foraged for animals in different habitats was not significantly different $(\mathrm{P}=0.061$; Fig. 3a). Conversely, the proportion of the time budget that individuals foraged for and ate fruits, flowers, and nectar varied among habitats $(\mathrm{P}<0.001$; Fig. 3b). Multiple comparisons revealed that lion tamarins spent a greater proportion of time foraging

Table 1 Structural characteristics of four habitat types used by golden-headed lion tamarins. Unless otherwise indicated, numbers represent the mean per ha \pm SD. A MANOVA indicated that resources varied among the four habitats (Wilks' $\Lambda=0.3091 ; F_{12,63.79}=2.97$ ). Univariate ANOVAs also revealed differences among total trees $\left(F_{3,28}=3.35 ; \mathrm{P}=0.034\right)$, total bromeliads $\left(F_{3,28}=2.89 ; \mathrm{P}=0.054\right)$ and total foraging sites $\left(F_{3,28}=9.98 ; \mathrm{P}<0.001\right)$, but not between total number of tree holes $\left(F_{3,28}=1.39 ; \mathrm{P}=0.266\right)$. Significant differences in pairwise comparisons of habitat variables between habitats are indicated by values that do not share a common letter in the upper right corner.

\begin{tabular}{|c|c|c|c|c|}
\hline \multirow[b]{2}{*}{ Habitat variable } & \multicolumn{4}{|c|}{ Habitat types } \\
\hline & Mature & Secondary & Swamp & Cabruca \\
\hline \multicolumn{5}{|l|}{ No. of trees } \\
\hline Total & $9.80 \pm 3.24^{\mathrm{a}}$ & $5.28 \pm 1.49^{\mathrm{bc}}$ & $7.10 \pm 1.56^{\mathrm{ab}}$ & $4.08 \pm 0.95^{\mathrm{cd}}$ \\
\hline $10-20 \mathrm{DBH}^{1}$ & $6.20 \pm 2.92$ & $4.03 \pm 1.29$ & $4.08 \pm 1.49$ & $1.29 \pm 0.62$ \\
\hline 20-30 DBH & $2.18 \pm 0.54$ & $1.03 \pm 0.51$ & $1.95 \pm 1.06$ & $1.19 \pm 0.33$ \\
\hline 30-40 DBH & $1.05 \pm 0.83$ & $0.13 \pm 0.15$ & $0.90 \pm 0.67$ & $0.98 \pm 0.67$ \\
\hline$>40 \mathrm{DBH}$ & $0.38 \pm 0.20$ & $0.10 \pm 0.15$ & $0.18 \pm 0.13$ & $0.62 \pm 0.30$ \\
\hline \multicolumn{5}{|l|}{ No. of bromeliads } \\
\hline Total & $3.62 \pm 2.90^{\mathrm{a}}$ & $0.08 \pm 0.21^{\mathrm{b}}$ & $1.98 \pm 1.08^{\mathrm{a}}$ & $1.26 \pm 1.0^{\mathrm{a}}$ \\
\hline Small & $2.67 \pm 2.60$ & 0.00 & $0.95 \pm 0.55$ & $0.64 \pm 0.87$ \\
\hline Medium & $0.66 \pm 0.38$ & $0.08 \pm 0.21$ & $0.73 \pm 0.59$ & $0.29 \pm 0.25$ \\
\hline Large & $0.30 \pm 0.39$ & 0.00 & $0.30 \pm 0.19$ & $0.33 \pm 0.25$ \\
\hline \multicolumn{5}{|l|}{ No. of alternative foraging sites } \\
\hline Total & $2.40 \pm 0.67^{\mathrm{a}}$ & $1.43 \pm 1.03^{\mathrm{ac}}$ & $2.20 \pm 1.32^{\mathrm{a}}$ & $0.82 \pm 0.38^{\mathrm{bc}}$ \\
\hline Rotting wood & $2.05 \pm 0.80$ & $1.00 \pm 1.09$ & $2.15 \pm 1.20$ & $0.82 \pm 0.38$ \\
\hline Piaçava palm & $0.35 \pm 0.38$ & 0.00 & $0.05 \pm 0.14$ & 0.00 \\
\hline Dendê palm & 0.00 & $0.50 \pm 0.59$ & 0.00 & 0.00 \\
\hline No. of tree holes & $0.38 \pm 0.53$ & 0.00 & $0.38 \pm 0.53$ & $0.31 \pm 0.54$ \\
\hline Presence or absence of lianas ${ }^{2}$ & $0.83 \pm 0.17$ & $0.69 \pm 0.31$ & $0.56 \pm 0.25$ & $0.08 \pm 0.15$ \\
\hline
\end{tabular}

${ }^{1} \mathrm{DBH}$, diameter at breast height

${ }^{2}$ Proportion of quadrats within a transect that contained lianas 
Table 2 Habitat selection by three groups of golden-headed lion tamarins, comparing the observed number of scans in each habitat with that expected if groups were using habitats in relation to their availability.

\begin{tabular}{|c|c|c|c|c|c|c|c|c|c|}
\hline \multirow[b]{3}{*}{ Habitat } & \multicolumn{9}{|c|}{ Group } \\
\hline & \multicolumn{3}{|c|}{ Piaçava $^{1}$} & \multicolumn{3}{|c|}{ Onça $^{1}$} & \multicolumn{3}{|c|}{ Entulho $^{2}$} \\
\hline & Obs. & Exp. & Dev. ${ }^{3}$ & Obs. & Exp. & Dev. & Obs. & Exp. & Dev. \\
\hline Mature & 176 & 218 & - & 145 & 118 & + & 8 & 8 & \\
\hline Secondary & 39 & 37 & & 116 & 207 & - & 160 & 145 & + \\
\hline Swamp & 51 & 36 & & 55 & 38 & + & 4 & 19 & - \\
\hline Cabruca & 200 & 175 & & 43 & 31 & & NA & NA & \\
\hline
\end{tabular}

${ }^{1} \chi^{2} \mathrm{P}<0.001$

${ }^{2} \chi^{2} \mathrm{P}<0.01$

${ }^{3}$ Significant deviation $(+$ or -$)$ is based on confidence intervals following techniques from Neu et al. (1974)

Table 3 A comparison of the number of sleeping sites (tree holes and vine tangles) selected in each habitat to that expected if groups of golden-headed lion tamarins chose sleeping sites in proportion to the amount of each type of habitat available in their home range.

\begin{tabular}{|c|c|c|c|c|c|c|}
\hline \multirow[b]{3}{*}{ Habitat Type } & \multicolumn{6}{|c|}{ Group } \\
\hline & \multicolumn{2}{|c|}{ Piaçava* } & \multicolumn{2}{|c|}{ Onça** } & \multicolumn{2}{|c|}{ Entulho ${ }^{* * *}$} \\
\hline & Obs. & Exp. & Obs. & Exp. & Obs. & Exp. \\
\hline Mature & 20 & 25.3 & 44 & 19.8 & 11 & 1.7 \\
\hline Secondary & 4 & 4.3 & 8 & 34.6 & 27 & 32.0 \\
\hline Swamp & 0 & 4.1 & 5 & 6.4 & 0 & 4.2 \\
\hline Cabruca & 30 & 20.3 & 9 & 5.2 & $\mathrm{NA}^{1}$ & NA \\
\hline
\end{tabular}

${ }^{*} \mathrm{P}<0.05,{ }^{* *} \mathrm{P}<0.001,{ }^{* * *} \mathrm{P}<0.0001$

${ }^{1}$ Not applicable

for and eating fruits, flowers, and nectar in cabruca than in mature $\left(t_{42}=7.22, \mathrm{P}<0.001\right)$ or secondary forests $\left(t_{42}=4.96, \mathrm{P}<0.001\right)$, and in swamp than in mature forests $\left(t_{42}=-4.70, \mathrm{P}<0.001\right)$.

\section{Discussion}

Our data suggest that golden-headed lion tamarins select tall forest for sleeping at night. Relative to the amount of available habitat, all groups tended to use sleeping sites in mature forest or cabruca and avoided sleeping in swamp or secondary forests. We were unable to distinguish whether groups did so because they prefer sleeping in these habitats or because more sleeping sites were available. This was in part because our method of sampling for tree holes underestimated their actual availability in secondary forest. Although we did not record any tree holes in secondary forest during our transect surveys, golden-headed lion tamarins that we followed did sleep in tree holes in this habitat. In particular, Entulho used sleeping sites in secondary forest more frequently than the other groups; however, the group's home range was located almost entirely within that habitat type. Interestingly, this group was also the only group to sleep in vine tangles, which were also present in mature habitat, but never used. Vine tangles clearly represent an alternative resource when tree holes are less abundant.

Golden-headed lion tamarins did not show overall preferences for secondary forest, contrary to what has been suggested for other callitrichid genera. Two of the three groups used secondary forests less than or in relation to its availability, and secondary forests were not used more than other habitats to search for insects or fruits and flowers. From transect sampling we determined that secondary forests contained fewer bromeliads than other habitats, indicating that secondary forest may not represent the most profitable habitat for locating animal prey. In studies of birds, insectivorous species were more diverse and common in old-growth forests than in young secondary forests (Blake \& Loiselle, 2001). We do not have evidence for whether or not there is a greater abundance of fruit in secondary forests. In our study, only one group, Entulho, preferentially used secondary forest. However, the home range of that group contained no cabruca, and only relatively small areas of other habitats.

Cabruca appeared to offer more adequate resources to the tamarins than were available in secondary forests. Golden-headed lion tamarins did not avoid cabruca when it was available, and occasionally would spend entire days within this forest type (pers. obs.). Although much of the understory in cabruca has been removed to plant cacao trees, the habitat represented an important source of fruit and flowers, animal prey and sleeping sites. The percentage of time spent foraging for insects was similar in cabruca and other habitats, and the percentage of time spent foraging and eating fruits, flowers, and nectar was higher in cabruca than in mature or secondary forests. Cabruca did not have as many alternative prey foraging sites relative to mature or swamp forests but seemed to have equal densities of large bromeliads. Large bromeliads are rich patches of invertebrate and vertebrate prey (Domingues et al., 1989). Although cabruca had fewer total trees than mature forest, it did have equal densities of the largest tree class size ( $>40 \mathrm{~cm}$ diameter at breast height). Despite the potential foraging advantages of cabruca, golden-headed lion tamarins may still suffer costs while travelling within this habitat. Cabruca had very few connecting vines between trees relative to other habitats, potentially inhibiting locomotion and escape from predators.

Golden-headed lion tamarins in Una Reserve did not select swamp over other available habitats, in contrast to the findings of Dietz et al. (1997) for L. rosalia in Poço das 

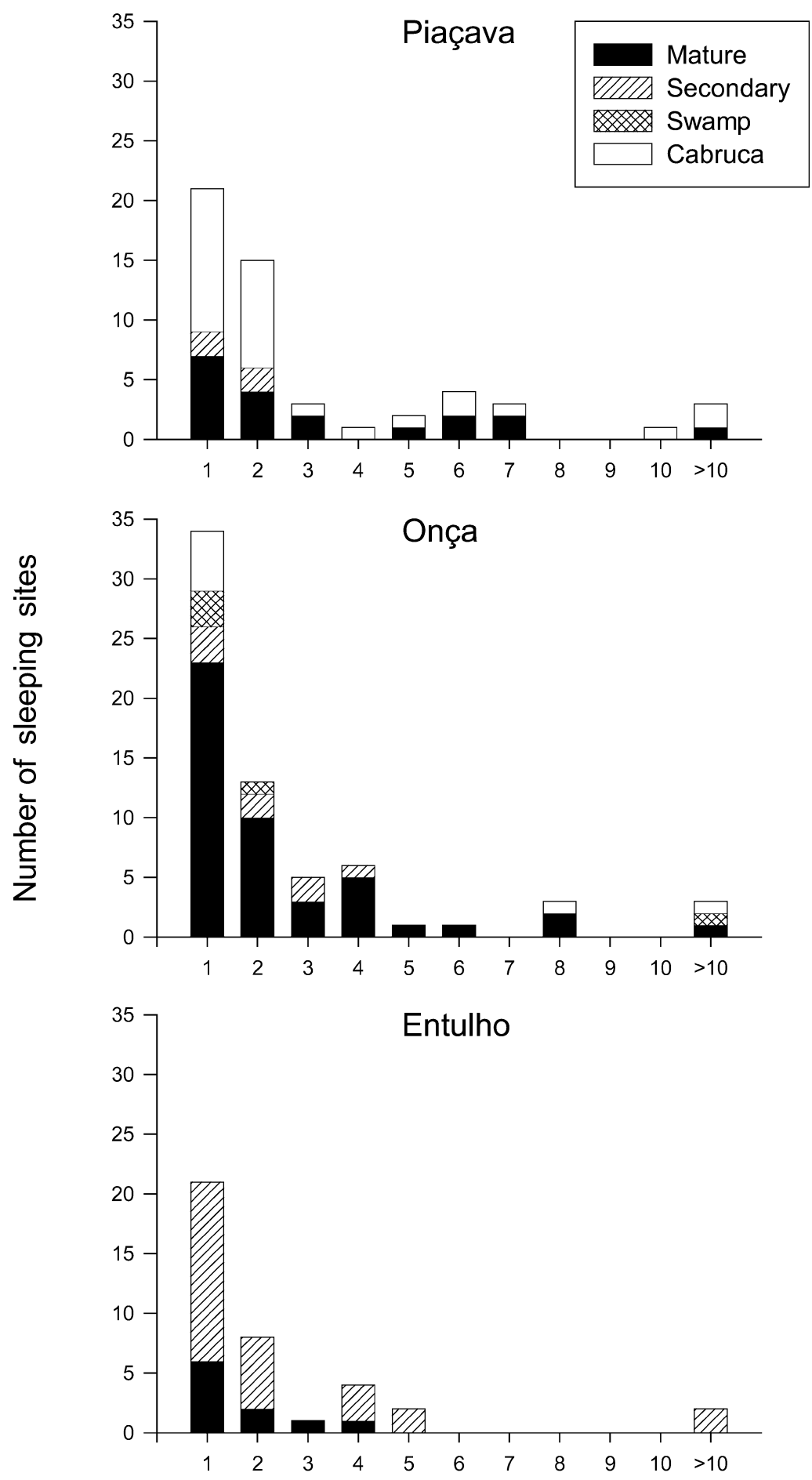

Number of times a sleeping site was used

Fig. 2 Repeated use of sleeping sites in mature, secondary, swamp and cabruca forest. $\mathrm{N}=54$, 65 and 38 sleeping sites for Piaçava, Onça and Entulho respectively.
Antas Biological Reserve. Dietz et al. (1997) suggested the tamarins' preference for swamp was due to more humid microclimates, favourable in terms of the abundance of animal prey during the dry season. The eastern part of the golden-headed lion tamarins' range, including our study site, does not have any seasonality in its rainfall (Rylands, 1993). Although the extent of fluctuations in food resources is unknown, the lack of a distinct dry season at Una may provide more stable prey resources throughout the year. 


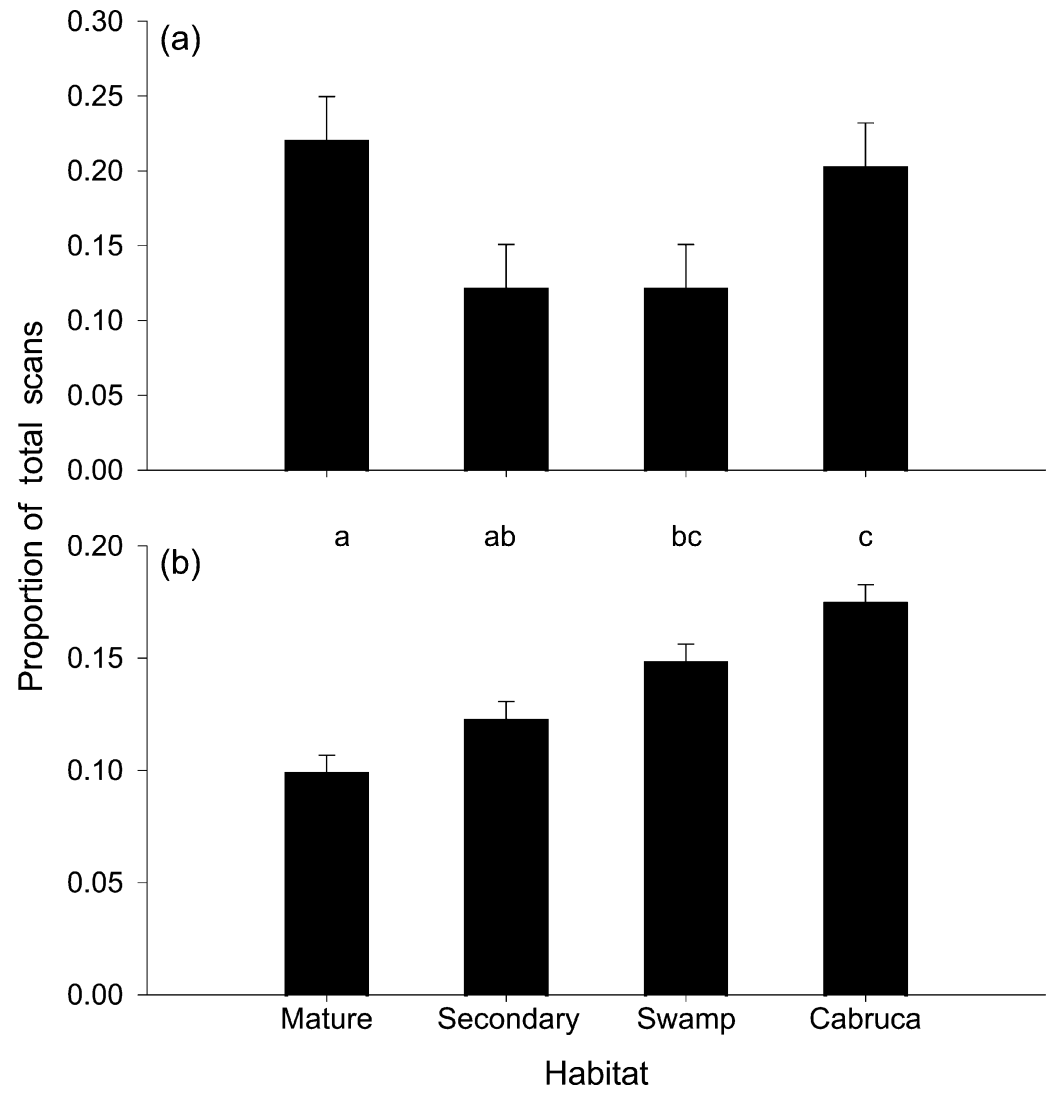

Fig. 3 The average proportion of the time budget \pm SEM spent by individuals a) foraging for animals and $b$ ) foraging and eating plants in each habitat. ANOVAs revealed there were no significant differences in the percentage of time spent foraging for animals $\left(F_{3,2.9}=8.27, \mathrm{P}=0.062\right)$ but there were for the percent age of time spent foraging or eating fruit, flowers and nectar $\left(F_{3,42}=19.37\right.$, $\mathrm{P}<0.001)$. Significant differences from pairwise comparisons are indicated by bars that do not share a common letter.
Given the rapid rate of habitat loss in southern Bahia, the fact that golden-headed lion tamarins preferentially selected sleeping sites in habitats with tall forest and/or that more sleeping sites were available in tall forest raises additional concerns about conservation of the species. The use of poorly protected sleeping sites (e.g. exposed sites such as hollow tree stumps and sites near to the ground or on branches) in the degraded forests of Poço das Antas Reserve may explain the recent occurrences of predation on complete groups of $L$. rosalia in that reserve (Dietz \& Baker, unpub. data). Our results suggest that lion tamarins will sleep in degraded areas when faced with limited options, but frequently select tall forest habitats when available.

The forest structure of cabruca is similar to shadecoffee plantations, a habitat that has been documented to have high diversity of birds and has been a focus of conservation concern throughout the tropics (Sherry, 2000). Many rainforest species are likely to suffer population declines if landowners continue to convert their shade-coffee or cabruca forests into monoculture crops or cattle ranches. In the past 14 years cocoa production in Southern Bahia has faced severe problems, including the rapid spread of a fungal disease, witches' broom (Alger \& Caldas, 1994; Saatchi et al., 2001). As the price of cocoa falls, farmers are forced to seek alternative sources of income by converting cabruca and forests into cattle pasture (Nobre, 1998; Saatchi et al., 2001). In so doing, they are eliminating habitat for many threatened species. A recent study of biodiversity in the Una region indicated that cabruca forests maintained at least $70 \%$ of the terrestrial frog and lizard, small mammal and bat species that are found in neighbouring intact forests (Dixo, 2001; Pardini, 2001; Faria, 2002).

Golden-headed lion tamarins did not preferentially use degraded and regenerating habitats, but neither did they avoid them. We suggest that regenerating secondary forests and cabruca forests may be considered as suitable habitat for corridors facilitating the movement of the tamarins between larger tracts of intact forest. The majority of the secondary forest at our study site was approximately 30 years old at the time of the study. We do not know the full extent to which golden-headed lion tamarins use younger forests, although we have tracked tamarins passing through fields and newly regenerating forests $<10$ years old.

In this study we showed that golden-headed lion tamarins used all forested habitats that were available. Home ranges with heterogeneous habitat structure may offer more resources, or more flexible access to resources, than home ranges containing only one habitat type. Habitat heterogeneity has been shown to be positively 
correlated with primate abundance and species richness (Stallings \& Robinson, 1991) and may decrease the probability of local extinctions. Thomas (1991) suggested that secondary forests in Zaire supply important lower quality resources to Cercopithecus monkeys to supplement the seasonal productivity in primary forest in drier periods, and found the highest densities of Cercopithecus in areas that had such habitat mosaics. Mosaics of old and young forest have also been suggested to be important in maintaining high levels of bird diversity at La Selva Biological Station in Costa Rica (Blake \& Loiselle, 2001). Similarly, we suggest that habitat mosaics containing tall forest, either mature or cabruca, will be important to long-term conservation of golden-headed lion tamarins.

\section{Acknowledgements}

Funding was provided by the Durrell Wildlife Conservation Trust, the Lion Tamarins of Brazil Fund, Margot Marsh Biodiversity Foundation, the Tulsa Zoo, Sigma $\mathrm{Xi}$, an NSF Research and Training Grant to University of Maryland and a Eugenie Clark Fellowship to B.E. Raboy. For field assistance we thank Gilvan Gomes Mota and Giomário Santos Souza. Annie G. Bush assisted us with GIS. Aerial and base maps of Una Reserve were provided by the Brazilian Institute for the Environment and Renewable Natural Resources (IBAMA) and the Institute for Social and Environmental Studies of Southern Bahia. We are grateful for the help and support provided by Saturnino N. de Sousa and Jeremy Mallinson. We acknowledge The Brazilian Science Council and IBAMA for permission to conduct our project in Una Biological Reserve. We thank Stacey Lance, Kristel De Vleeschouwer and Sarah Hankerson for comments on earlier versions of this manuscript.

\section{References}

Alger, K. \& Caldas, M. (1994) The declining cocoa economy and the Atlantic forest of Southern Bahia, Brazil: conservation attitudes of cocoa planters. The Environmentalist, 14, 107-119.

Altmann, J. (1974) Observational study of behavior: sampling methods. Behaviour, 49, 227-267.

Bicca-Marques, J.C. (1999) Hand specialization, sympatry, and mixed-species associations in callitrichines. Journal of Human Evolution, 36, 349-378.

Blake, J.G. \& Loiselle, B.A. (2001) Bird assemblages in second-growth and old-growth forests, Costa Rica: perspectives from mist nets and point counts. The Auk, 118, 304-326.

Coimbra-Filho, A.F. (1978) Natural shelters of Leontopithecus rosalia and some ecological implications (Callitrichidae: Primates). In The Biology and Conservation of the Callitrichidae (ed. D.G. Kleiman), pp. 79-89. Smithsonian Institution Press, Washington, DC, USA.
Dietz, J.M., de Sousa, S.N. \& Billerbeck, R. (1996) Population dynamics of golden-headed lion tamarins Leontopithecus chrysomelas in Una Reserve, Brazil. Dodo, Journal of the Wildife Preservation Trust, 32, 115-122.

Dietz, J.M., Peres, C.A. \& Pinder, L. (1997) Foraging ecology and use of space in wild golden lion tamarins (Leontopithecus rosalia). American Journal of Primatology, 41, 289-305.

Dixo, M.B.O. (2001) Efeito da fragmentação da floresta sobre a comunidade de sapos e lagartos de serapilheira no Sul da Bahia. MSc thesis, Universidade de São Paulo, São Paulo, Brazil.

Domingues, R.A.P., Pugialli, H.R.L. \& Dietz, J.M. (1989) Densidade e diversidade de fauna fitotelmata em bromélias de quatro tipos de florestas degradadas. Revista Brasileira de Biologia, 49, 125-129.

Egler, S.G. (1992) Feeding ecology of Saguinus bicolor bicolor (Callitrichidae: Primates) in a relict forest in Manaus, Brazilian Amazonia. Folia Primatologica, 59, 61-67.

Faria, D.M. (2002) Comunidade de morcegos em uma paisagem fragmentada da mata Atlântica do sul da Bahia, Brasil. PhD thesis, Universidade Estadual de Campinas, Campinas, Brazil.

Ferrari, S.F. \& Diego, V.H. (1995) Habitat fragmentation and primate conservation in the Atlantic Forest of eastern Minas Gerais, Brazil. Oryx, 29, 192-196.

Hooge, P.N. \& Eichenlaub, B. (1997) Animal Movement Extension to Arcview, Ver. 1.1. Alaska Biological Science Center, US Geological Survey, Anchorage, USA.

IUCN (2002) 2002 IUCN Red List of Threatened Species. IUCN, Gland, Switzerland [http:/ / www.redlist.org, accessed 25 September 2003].

Johns, A.D. (1991) Forest disturbance and Amazonian primates. In Primate Responses to Environmental Change (ed. H.O. Box), pp. 115-135. Chapman and Hall, London, UK.

Johns, A.D. \& Skorupa, J.P. (1987) Responses of rain-forest primates to habitat disturbance: a review. International Journal of Primatology, 8, 157-191.

Lidicker, W.Z., Jr. \& Koenig, W.D. (1996) Responses of terrestrial vertebrates to habitat edges and corridors. In Metapopulation and Wildlife Conservation (ed. D.R. McCullough), pp. 85-109. Island Press, Washington, DC, USA.

Mallinson, J.J.C. (2001) Saving Brazil's Atlantic rainforests: Using the golden-headed lion tamarin Leontopithecus chrysomelas as a flagship for a biodiversity hotspot. Dodo, Journal of the Wildlife Preservation Trust, 37, 9-20.

Martin, T.E. (1985) Selection of second-growth woodlands by frugiverous migrating birds in Panama: an effect of fruit size and plant density? Journal of Tropical Ecology, 1, 157-170.

Mittermeier, R.A., Coimbra-Filho, A.F., Constable, A.F., Rylands, A.B. \& Valle, C. (1982) Conservation of primates in the Atlantic Forest region of eastern Brazil. International Zoo Yearbook, 22, 2-17.

Neu, C.W., Byers, C.R. \& Peek, J.M. (1974) A technique for analysis of utilization-availability data. Journal of Wildlife Management, 38, 541-545.

Nobre, S.S. (1998) The Atlantic rainforest in the Brazilian cocoa region. Applied Geography and Development, 52, 41-51.

Pardini, R. (2001) Pequenos mamiferos e a fragmentação da Mata Atlântica de Una, Sul da Bahia, Brasil. PhD thesis, Univerisdade Estadual de Campinas, Campinas, Brazil.

Passamani, M. \& Rylands, A.B. (2000) Feeding behavior of Geoffroy's Marmoset (Callithrix geoffroyi) in an Atlantic forest fragment of south-eastern Brazil. Primates, 41, 27-38.

Peres, C.A. (1986) Costs and benefits of territorial defense in golden lion tamarins, Leontopithecus rosalia. $\mathrm{PhD}$ thesis, University of Florida, Gainesville, USA. 
Prado, F. (1999) Ecologia, comportamento e conservação do mico-leão-da-cara-preta (Leontopithecus caissara) no Parque Nacional do Superagui, Guaraqueçaba, Paraná. MSc thesis, Universidade Estadual Paulista, Botcatu, Brazil.

Raboy, B.E. (2002) The ecology and behavior of wild golden-headed lion tamarins (Leontopithecus chrysomelas). PhD thesis, University of Maryland, College Park, USA.

Rylands, A.B. (1982) The behavior and ecology of three species of marmosets and tamarins (Callitrichidae, Primates) in Brazil. PhD thesis, University of Cambridge, Cambridge, UK.

Rylands, A.B. (1986) Ranging behaviour and habitat preference of a wild marmoset group, Callithrix humeralifer (Callitrichidae, Primates). Journal of Zoology, London, 210, 489-514.

Rylands, A.B. (1989) Sympatric Brazilian callitrichids: the black tufted-ear marmoset, Callithrix kuhli, and the golden-headed lion tamarin, Leontopithecus chrysomelas. Journal of Human Evolution, 18, 679-695.

Rylands, A.B. (1993) The ecology of the lion tamarins, Leontopithecus: some intrageneric differences and comparisons with other callitrichids. In Marmosets and Tamarins: Systematics, Behaviour, and Ecology (ed. A.B. Rylands), pp. 296-313. Oxford University Press, Oxford, UK.

Rylands, A.B. (1996) Habitat and the evolution of social and reproductive behavior in the Callitrichidae. American Journal of Primatology, 38, 5-18.

Rylands, A.B., da Fonseca, G.A.B., Leite, Y.L.R. \& Mittermeier, R.A. (1996) Primates of the Atlantic forest: origin, distributions, endemism, and communities. In Adaptive Radiations of Neotropical Primates (eds M.A. Norconk, A.L. Rosenberger \& P.A. Garber), pp. 21-51. Plenum Press, New York, USA.

Saatchi, S., Agosti, D., Alger, K., Delabie, J. \& Musinsky, J. (2001) Examining fragmentation and loss of primary forest in the Southern Bahian Atlantic Forest of Brazil with radar imagery. Conservation Biology, 15, 867-875.

Sherry, T.W. (2000) Shade coffee: a good brew even in small doses. The Auk, 117, 563-568.

Sokal, R.R. \& Rohlf, F.J. (1995) Biometry. W.H. Freeman, New York, USA.

Stallings, J.R. \& Robinson, J.G. (1991) Disturbance, forest heterogeneity and primate communities in a Brazilian Atlantic forest park. A Primatologia no Brasil, 3, 357-368.
Sussman, R.W. \& Kinzey, W.G. (1984) The ecological role of the Callitrichidae: a review. American Journal of Physical Anthropology, 64, 419-449.

Terborgh, J. (1983) Five New World Primates. Princeton University Press, Princeton, USA.

Thomas, S.C. (1991) Population densities and patterns of habitat use among anthropoid primates of the Ituri forest, Zaire. Biotropica, 23, 68-83.

Turner, B.L., Clark, W.C. \& Kates, R.W. (eds) (1990) The Earth as Transformed by Human Action: Global and Regional Changes in the Biosphere over the past 300 Years. Cambridge University Press, Cambridge, UK.

Worton, B.J. (1986) A review of models of home range for animal movement. Ecological Modeling, 38, 277-298.

Worton, B.J. (1989) Kernel methods for estimating the utilization distribution in home-range studies. Ecology, 70, 164-168.

\section{Biographical sketches}

Becky Raboy has studied the ecology and behaviour of wild golden-headed lion tamarins and Wied's black tufted-ear marmosets Callithrix kuhli. She spent the last several years developing infrastructure at Una Biological Reserve in Southern Bahia, Brazil, to carry out long-term monitoring of the population of golden-headed lion tamarins.

Mary Christman's principle research interest is the application of statistical methods to ecological and environmental modelling. Her related research interests include statistical analyses of animal movement and behaviour and statistical spatial modelling.

For the past 17 years James Dietz has been studying the behavioural ecology of golden and golden-headed lion tamarins in south-eastern Brazil. His research on the evolution of mating systems and helping behaviour in these communally breeding primates forms an integral part of international projects targeting the conservation of these threatened species and the biodiversity of their ecosystems. 